\section{International Scientific Journal Theoretical \& Applied Science}

\author{
p-ISSN: 2308-4944 (print) e-ISSN: 2409-0085 (online) \\ Year: $2016 \quad$ Issue: $10 \quad$ Volume: 42
}

Published: $30.10 .2016 \quad$ http://T-Science.org

SECTION 2. Applied mathematics. Mathematical modeling.
Mohiniso Bahromovna Hidirova

$\mathrm{PhD}$, Senior Scientist, dept."Regulatorika"

Centre for the development of software and hardware program complexes at Tashkent University of Informational Technologies,

Tashkent, Uzbekistan regulatorika@yahoo.com

\section{Zaynabhon Djumanazarovna Yusupova}

Senior teacher of dept. "System and applied programming" Tashkent University of Informational Technologies Tashkent, Uzbekistan zaynabhon@inbox.ru

\title{
MATHEMATICAL MODEL OF THE REGULATORY MECHANISMS OF HUMAN CARDIOVASCULAR SYSTEM
}

Abstract: Nowadays there is a high degree of human deaths from heart disease requires us to carefully study the laws of regulatory cardiac activity. In this article we consider the problem of mathematical modeling of regulatory mechanisms of cardiac activity. At the same time built differential-difference equations, taking into account the delay in the distribution system of excitations in the heart cells and the feedback of the cardiac cycle, which let us explore various modes of the heart as a whole.

Key words: heart cells, mathematical modeling, the excitation of cell systems of heart, differential-difference equations with delay.

Language: English

Citation: Hidirova MB, Yusupova ZD (2016) MATHEMATICAL MODEL OF THE REGULATORY MECHANISMS OF HUMAN CARDIOVASCULAR SYSTEM. ISJ Theoretical \& Applied Science, 10 (42): 4-8.

Soi: http://s-o-i.org/1.1/TAS-10-42-2 Doi: crossef http://dx.doi.org/10.15863/TAS.2016.10.42.2

\section{Introduction}

Cardiovascular system (CVS) is the most important human organ, that is to say the motor body. The heart circulates the blood in the body in two circulatory systems: the pulmonary and systemic circulations. Currently, among the deaths from diseases leading cardiovascular disease [1].

10 leading causes of death in the world (in millions, 2012)

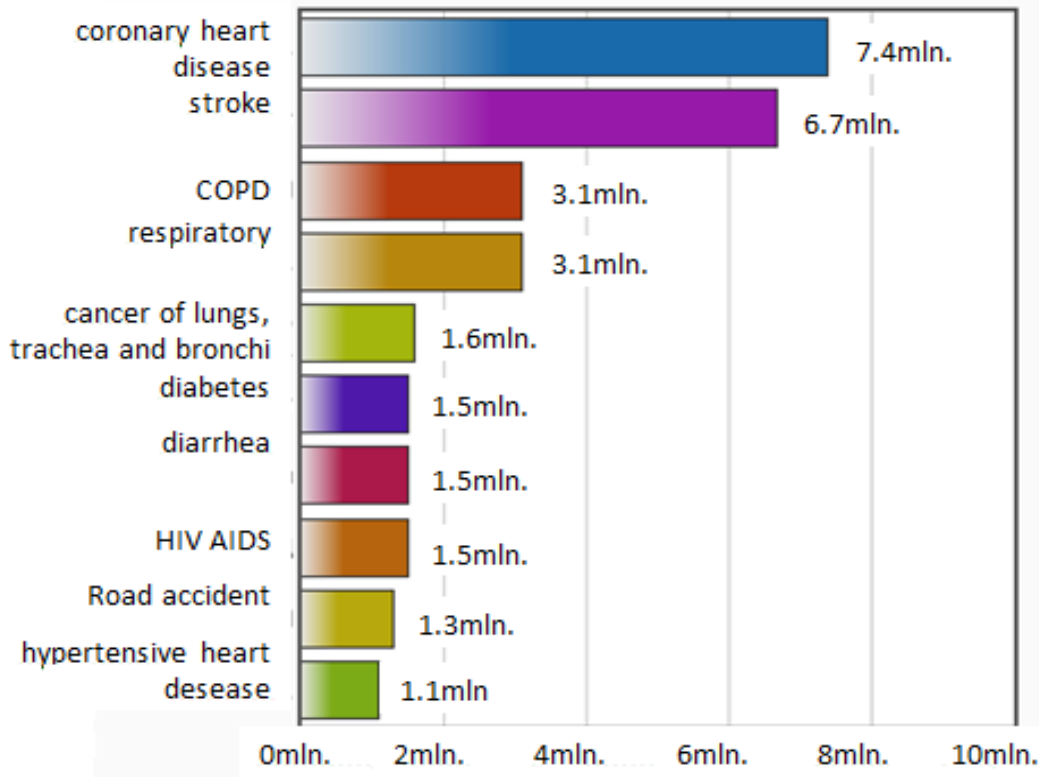

Number of deaths $(\mathrm{m} / \mathrm{n})$

Figure 1 - Statistics cause of death in the world [2]. 
According to the World Health Organization in 2012, 17.5 million people died from cardiovascular disease that is 3 of every 10 . Of this number, 7.4 million people died from ischemic heart disease and 6.7 million people from a stroke (Figure 1) [2].

This data causes a person to think, to explore, to study activity and regulatory mechanisms of cardiovascular system, causes of diseases, as well as mechanisms for the prevention, treatment of these diseases. Therefore, scientists are exploring features of the functioning of the cardiovascular system. We know that the study of cardiac activity can be better carried out by means of mathematical modeling of the heart. With this approach can be clearly aware of the regulatory mechanisms of the heart and its work in general.

Until now, it was built several mathematical models and studied cardiovascular system by the scientists.

According to the News Agency of Russia in 2014, specialists of the Ural Branch of the Russian Academy of Sciences, in collaboration with the universities of Oxford and Ghent have digitized the heart and created a fundamentally new model of the diagnostic system.

3D-mathematical model describes the mechanical and electrical phenomena of the heart and consists of 28 sets of differential and algebraic equations. By changing them, cardiologists will be able to carry out an extensive practice of the control of the intracellular processes that determine the behavior of the heart, as well as determine the effects of pharmacological agents on the course of biochemical reactions in the body [3].

Another mathematical model of CVS was offered by the Russian scientist, Professor of Tambov State Technical University S.V. Frolov, S.V. Sindeeva, V.A. Lischuk. In their work was implemented the mathematical description of the four-chamber model of the cardiovascular system with a beating heart. The cardiovascular system is represented as a series-connected four elastic chambers. A mathematical model of CVS, consisting of four series-connected elements: LH - left heart (LeftHeart); SC - the systemic circulation (SystemicCirculation); RH - right heart (RightHeart); PC - pulmonary circulation (PulmonaryCirculation). The composition of elements CVS includes serially connected chambers and valves. In the model each icamera of CVS is characterized by the functions , respectively volume flow, volume, pressure: $\mathrm{q}_{\mathrm{i}}(\mathrm{t}), \mathrm{V}_{\mathrm{i}}$ $(\mathrm{t}), \mathrm{P}_{\mathrm{i}}(\mathrm{t}), \mathrm{i} \in\{\mathrm{LH}, \mathrm{SC}, \mathrm{RH}, \mathrm{PC}\}$. Blood balance equations in the model chambers in differential form as follows [4]:

$$
\begin{aligned}
& \frac{d V_{L H}}{d t}=q_{P C}(t)-q_{L H}(t) \\
& \frac{d V_{S C}}{d t}=q_{L H}(t)-q_{S C}(t) \\
& \frac{d V_{R H}}{d t}=q_{S C}(t)-q_{R H}(t) \\
& \frac{d V_{P C}}{d t}=q_{R H}(t)-q_{P C}(t)
\end{aligned}
$$

The equations of motion for the flow recorded in the form of:

$$
\begin{gathered}
q_{L H}(t)=\frac{1}{R_{L H}(t)}\left(P_{P C}(t)-P_{L H}(t)\right) \\
\frac{d q_{S C}(t)}{d t}=\frac{1}{L_{S C}}\left(P_{L H}(t)-P_{S C}(t)-R_{S C}(t) q_{S C}(t)\right) \\
q_{R H}(t)=\frac{1}{R_{R H}(t)}\left(P_{S C}(t)-P_{R H}(t)\right) \\
\frac{d q_{P C}(t)}{d t}=\frac{1}{L_{P C}}\left(P_{R H}(t)-P_{P C}(t)-R_{P C}(t) q_{P C}(t)\right)
\end{gathered}
$$




\begin{tabular}{|c|c|c|c|c|c|c|}
\hline Impact Factor: & $\begin{array}{l}\text { ISRA (India) } \\
\text { ISI (Dubai, UAE } \\
\text { GIF (Australia) } \\
\text { JIF }\end{array}$ & $\begin{array}{l}=1.344 \\
=0.829 \\
=0.564 \\
=1.500\end{array}$ & $\begin{array}{l}\text { SIS (USA) } \\
\text { PИНЦ (Russia) } \\
\text { ESJI (KZ) } \\
\text { SJIF (Morocco) }\end{array}$ & $\begin{array}{l}=0.912 \\
=0.234 \\
=1.042 \\
=2.031\end{array}$ & $\begin{array}{l}\text { ICV (Poland) } \\
\text { PIF (India) } \\
\text { IBI (India) }\end{array}$ & $\begin{array}{l}=6.630 \\
=1.940 \\
=4.260\end{array}$ \\
\hline
\end{tabular}

Dependence function of pressure $P_{i}(t)$ for $\mathrm{i} \in\{\mathrm{SC}, \mathrm{PC}\}$ function from volume $\mathrm{V}_{\mathrm{i}}(\mathrm{t})$ is written as Frank equation:

$$
\begin{gathered}
P_{S C}(t)=\frac{1}{C_{S C}}\left(V_{S C}(t)-U_{S C}\right) \\
P_{P C}(t)=\frac{1}{C_{P C}}\left(V_{P C}(t)-U_{P C}\right)
\end{gathered}
$$

Thus, a closed system of equations (1-10) of model are determines four chambers human cardiovascular system, and is oriented for use in intensive therapy.

It is an effective study of cardiac tissue excitement by combining modeling of regulatory of cardiac activity on the basis of a quantitative description of the excitation of the heart tissue cells and consistency of the feedback loop. In this case, the heart appears as the excitable medium consisting of regulatory cells (pacemakers), as well as cells that can receive and transmit the excitement and feedback system that allows control of the heart rhythm. Accounting of temporary relationships in the system of regulation of heart in the modeling leads to a functional-differential equations of delay type [6-12]. These models can be used to analyze cardiac tissue excitation mechanisms as the regulatory system. Let us turn to a brief consideration of one of the options for setting the equations of these models.

The CVS provides simulation physiology and function of the heart and its departments.

CVS can be viewed as a system consisting of three parts: the pacemaker area and the left and right part (atrium and ventricle) of the heart.

It is known that the Uzbek scientist B.N.Hidirov introduced the new concept of «OrAsta» in the direction of research of mathematical modeling of living systems regulatory mechanisms. Or (oscillator regulator) - the system regulator, Asta (active system with time average) controlled environment. This means that each dynamic system has a controller of system, which receives, processes and transmits information of specific nature and controlled environment, which is involved in the regulation mechanism responsible for biofeedback [12].

In our case, the heart also can be considered as a OrAsta - Or is the pacemaker area, generating pulse signals and transmitted to the parts of the heart, asta is a left and right side of the heart, which receive signals from pacemaker zone and as a result there is the excitement of the heart fibers, and on the basis of this happens systolic and diastolic rhythms of the cardiac cycle. Mathematical models of this Uzbek scientist are different from existing models with its characteristics of taking into account the delay time between Or and Asta in the differential-difference equations. Based on these features, you can explore the all possible regulatory regimes of living systems.

For the study, the most common laws of behavior of this model, the qualitative analysis of mechanisms of regulation of cardiac activity in normal and anomalies can be seen the following reduced system:

$$
\begin{gathered}
\frac{d X(t)}{d t}=a_{1} Y(t-1) Z(t-1) e^{-(Y(t-1)+Z(t-1))}-X(t) \\
\frac{d Y(t)}{d t}=a_{2} X(t)-Y(t) \\
\frac{d Z(t)}{d t}=a_{3} X(t)-Z(t)
\end{gathered}
$$

Here, $\mathrm{X}(\mathrm{t}), \mathrm{Y}(\mathrm{t}), \mathrm{Z}(\mathrm{t})$ are values of expressing, respectively, the activity of the pacemaker zone and departments (the left and right atrias and ventricles) of the heart; $a_{i}$ are positive constants $(i=1,2,3)$.

Built a computer model of these differentialdifference equations and the study them allowed us to figure out the different modes of regulatory mechanisms of the heart, such as a stationary state, vibrational, and chaotic "black hole effect" as shown in Figure 2. 


\begin{tabular}{|c|c|c|c|c|c|c|}
\hline Impact Factor: & $\begin{array}{l}\text { ISRA (India) } \\
\text { ISI (Dubai, UAE } \\
\text { GIF (Australia) } \\
\text { JIF }\end{array}$ & $\begin{array}{r}=1.344 \\
=0.829 \\
=0.564 \\
=1.500\end{array}$ & $\begin{array}{l}\text { SIS (USA) } \\
\text { PИНЦ (Russia) } \\
\text { ESJI (KZ) } \\
\text { SJIF (Morocco) }\end{array}$ & $\begin{array}{l}=0.912 \\
=0.234 \\
=1.042 \\
=2.031\end{array}$ & $\begin{array}{l}\text { ICV (Poland) } \\
\text { PIF (India) } \\
\text { IBI (India) }\end{array}$ & $\begin{array}{l}=6.630 \\
=1.940 \\
=4.260\end{array}$ \\
\hline
\end{tabular}

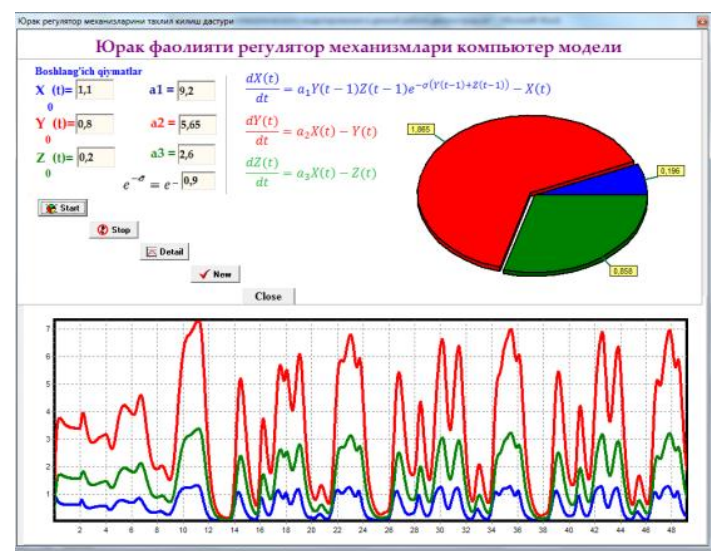

a) chaotic behavior CVS

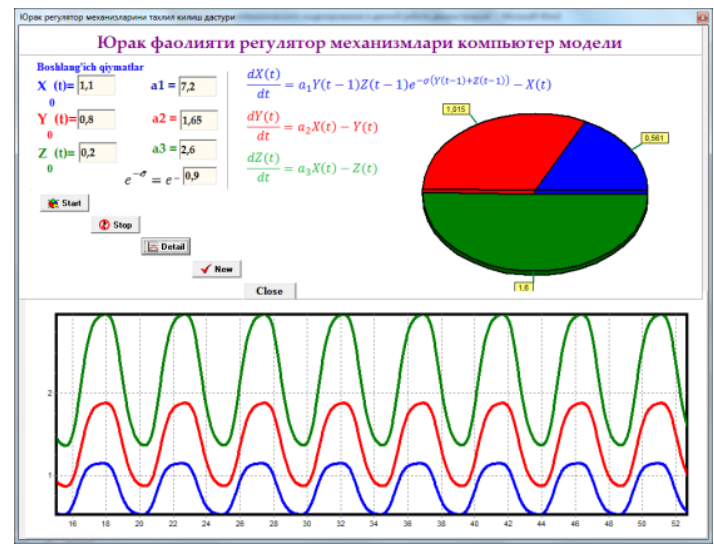

c) the state of oscillation

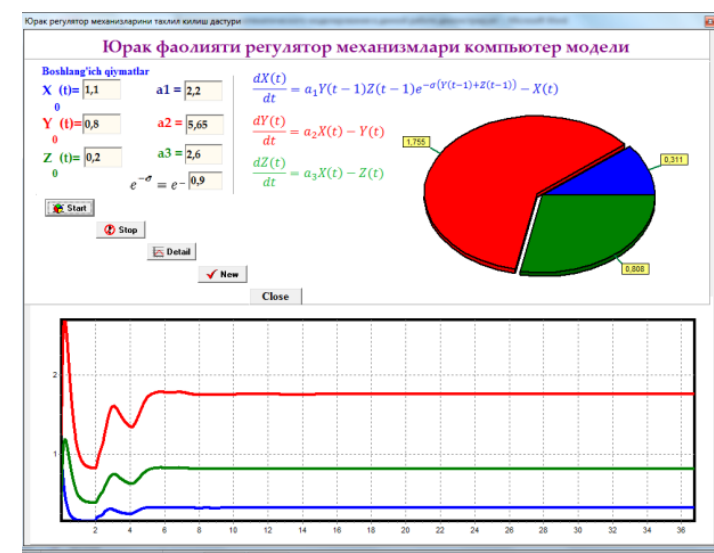

b) stationary behavior

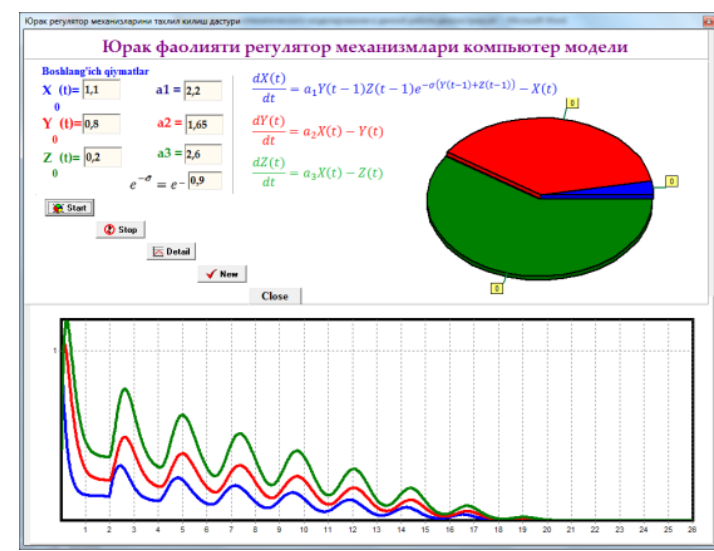

d) the state of decay

Figure 2 - Modes of heart.

The transition from one mode to another by changing the coefficient values.

\section{Conclusion}

Discussed in this article, the results of qualitative analysis of the equations (11) regulatory of cardiac tissue excitement show the existence of a stationary behavior of oscillation, irregular oscillations and "black hole" effect. In the case of identification with their modes of cardiac activity (normal, various forms of arrhythmias and sudden cardiac death, respectively) can be carried out modeling of specific diseases of the circulatory system.

Using mathematical modeling in this paper shows that the model can serve as an independent source of new knowledge and important tool for the study of physiological phenomena.

\section{References:}

1. (2016) The World Health Organization. Available:

http://www.who.int/mediacentre/factsheets/fs31 0/ru/index2.html (Accessed: 10.09.2016).

2. (2016) Available: http://droplak.ru/?p=2936 (Accessed: 10.09.2016).
3. (2016) Available: http://tass.ru/uralnews/1078142 (Accessed: 10.09.2016).

4. (2016) Available: https://scientificrussia.ru/articles/sozdanamatematicheskaya-model-serdtsa (Accessed: 10.09.2016). 


\begin{tabular}{l|lr|ll|ll} 
& ISRA (India) & $=\mathbf{1 . 3 4 4}$ & SIS (USA) & $=\mathbf{0 . 9 1 2}$ & ICV (Poland) & $=\mathbf{6 . 6 3 0}$ \\
Impact Factor: & ISI (Dubai, UAE) $=\mathbf{0 . 8 2 9}$ & PUHЦ (Russia) $=\mathbf{0 . 2 3 4}$ & PIF (India) & $=\mathbf{1 . 9 4 0}$ \\
& GIF (Australia) & $\mathbf{0 . 5 6 4}$ & ESJI (KZ) & $=\mathbf{1 . 0 4 2}$ & IBI (India) & $=\mathbf{4 . 2 6 0}$ \\
& JIF & $=\mathbf{1 . 5 0 0}$ & SJIF (Morocco) & $\mathbf{2 . 0 3 1}$ & & \\
\hline
\end{tabular}

5. Frolov SV, Sindeev SV, Lishchuk VA (2012) Four-chamber model of the human cardiovascular system // Questions of modern science and practice. University named after V.I. Vernadsky. 2012. № 2 (40). pp. 51-60.

6. Hidirova MB (2004) Modeling of mechanisms of cardiac tissue excitement // Mathematical modeling, 2004. T. 16. No 11. pp. 3-14.

7. Hidirova MB (2001) Biomechanics of cardiac activation: the simplest equations and modelling results //Russian Journal of Biomechanics, 2001. Vol. 5, № 2: 95-103.

8. Hidirova MB (1998) About one closed-loop model of the cardiovascular system (CVS): Mechanics of cardiac tissue excitement // Problems of Mechanics. - 1998. - № 2. pp.3943.
9. Hidirova MB (2003) Modelling of regulation mechanisms of cardiovascular systems. Scienticae Mathematicae Japonicae. Vol.8, 2003, pp. 427-432.

10. Hidirova MB (1998) About one closed-loop model of the cardiovascular system (CVS): Norm and cardiac anomaly // Problems of Mechanics. 1998. № 3. pp.29-33.

11. Hidirova MB (1998) About one closed-loop model of the cardiovascular system (CVS): Basic equations and results of computational experiments // Problems of Mechanics. - 1998. № 5. pp.26-30.

12. Hidirov BN (2014) Selected works on mathematical modeling of living systems regulatory. Moscow, Izhevsk: Institute of Computer Science, 2014. - 300 p. 